\title{
Erratum to: Twenty-first Century Governance Challenges in the Life Sciences
}

\section{Tatyana Novossiolova}

Erratum to:

Chapter 4 in: Twenty-first Century Governance Challenges in the Life Sciences, https://doi.org/10.1007/978-3-319-51004-0_4

The Publisher regrets that the below note [136] was missing in the original version of this chapter.

136. Jose-Luis Sagripanti, 'Building a Bio World', CBRNe World, October 2013, p.48, available at http://www.cbrneworld.com/_uploads/down load_magazines/Building_a_Bio_World.pdf (accessed 6 August 2017).

The updated online version for this chapter can be found at https://doi.org/10.1007/978-3-319-51004-0_4

(C) The Author(s) 2017

T. Novossiolova, Governance of Biotechnology in Post-Soviet Russia, Global Issues, DOI 10.1007/978-3-319-51004-0_9 